\title{
PLOUGH PARTS WEAR RESISTANCE DEPENDING ON THEIR MATERIAL COMPOSITION AND PROCESSING TECHNOLOGY
}

\author{
Martins Ziemelis, Gunars Verdins \\ Latvia University of Agriculture \\ martins.ziemelis@inbox.lv, gunars.verdins@1lu.lv
}

\begin{abstract}
Longevity of tillage tools mainly depends on their parts' material wear resistance and strength. The article summarizes information about steel physically-mechanical and exploitation characteristics that are most useful for soil tillage. The physical properties and the prices of chisels from various companies that are suitable for the company's "Kverneland" plows are analysed. Information about the chemical composition of materials that are suitable for the manufacturing of chisels is summarized. Practical study of plowing podzolic soil with the use of chisels from different companies is carried out. Chisel wear intensity in the soil is modelled depending on their performance properties. It is estimated that in the same soil composition, humidity, speed of the tillage and chisel hardness, wear resistance and the wear process for chisels is mainly dependent on the chemical composition of the used materials, their hardenability and heat treatment technologies.
\end{abstract}

Keywords: chisel, wear resistance, abrasion wear, boron steel, chemical composition.

\section{Introduction}

Longevity of soil treatment tools - plows, mills, harrows, discs and others - depends on wear and strength of their most vulnerable parts. The fastest diminishing parts for plows are plowshares, saddles and chisels. Wear intensity depends on the soil quality, qualities of the material used for the tool and many other factors. In the article [1] the factors that influence hydroabrasive wear $W$ are listed:

$W=f\left(t, a, \rho, H_{0}, F, v, \alpha, \eta\right)$, where: $t$ - duration of till; $a$ - structure of soil; $\rho$ - density of soil; $F$ - shape of abrasive parts; $H_{0}$ - hardness of soil; $v$ - speed of ploughing, $\alpha$ - angle of instrument emplacement; $\eta$ - quotient, which takes into account the properties at exploitation of the material used for the tool and their changes in the operating process. Effects of plough land moisture might be added. Besides, other types of wear are possible, as listed in other articles [2;3]: adhesion wear, corrosion wear (fretting), erosion wear, as well as such processes as cavitation, oxidation, bonding, material fatigue (fatigue).

The required physic-mechanical and operating properties of soil tillage tools are known, yet one material currently cannot provide all the necessary qualities, since these requirements are contradictory. Preferably, the material should be cheap, docile, wear-resistant, heat-improvable, corrosion resistant, with high bending strength, elastic. Since all the requirements cannot be met simultaneously, such plow coulter parts as chisels nowadays are made from steel, that can be consistently tempered to HRC $50 \pm 2$, the yield point of which is at least $350 \mathrm{MPa}$, the wear resistance is several times higher than in non-alloy steels at normalized state, and the price of which is not more than 1.5 times higher than that of non-alloy structural steels.

The aim of this article is to find out how coulter chisel wear is affected by the chemical composition, physical properties, performance and processing technology of the materials that are used in their manufacturing. To answer these questions, the authors must clarify which chemical composition is suitable for materials of plow spare parts, what the necessary physical and mechanical performance properties for chisels are, and what possibilities and technologies ensure these properties. Besides, chisel wear intensity must be verified in practice and the wear forecasts provided.

In practice, most commonly used material for the manufacture of active parts of agriculture machinery is boron steel. Such steel has been developed to improve hardenability during heat treatment by the deliberate addition of boron to a range of medium carbon steels. Boron steel hardenability is equivalent to that of much higher carbon steels and more expensive low alloy steels [4]. Widely applied wear resistant boron steel chemical composition [5-7] is provided in Table 1 below.

The chemical composition of the materials provided in Table 1 does not differ significantly - all steels contain carbon in range of 0.2-0.3\%; manganese 1.1-1.6\% ; silicon in ranges between 0.168$0.700 \%$; chrome varies $0.2-1.5 \%$, boron varies $0.001-0.005 \%$, but the amount of iron is $93.9-97.6 \%$. 
Wear-resistant boron steel chemical composition

\begin{tabular}{|c|c|c|c|c|c|c|c|c|c|c|}
\hline $\begin{array}{c}\text { Chemical } \\
\text { element }\end{array}$ & \multicolumn{9}{|c|}{ Designation of material } \\
\hline \% & $\begin{array}{c}\text { Hardox } \\
500\end{array}$ & $\begin{array}{c}\text { Relia } \\
500\end{array}$ & $\begin{array}{c}\text { AR } \\
500\end{array}$ & TBL & $495 \mathrm{~B}$ & 922 & B27 & HSBS & B1 & B2 \\
\hline $\mathbf{F e}$ & 95.9 & 95.0 & 93.8 & 97.8 & 98.0 & 97.0 & 97.6 & 97.0 & 97.2 & 97.3 \\
\hline $\mathbf{C}$ & 0.27 & 0.28 & 0.3 & 0.27 & 0.24 & $\begin{array}{c}0.25- \\
0.3\end{array}$ & 0.23 & 0.20 & 0.298 & 0.296 \\
\hline $\mathbf{S i}$ & 0.5 & 0.55 & 0.7 & 0.4 & 0.3 & $\begin{array}{c}0.20- \\
0.35\end{array}$ & 0.27 & 0.27 & 0.186 & 0.168 \\
\hline $\mathbf{M n}$ & 1.6 & 1.5 & 1.6 & 1.2 & 1.3 & $1.1-1.3$ & 1.33 & 1.26 & 1.18 & 1.10 \\
\hline $\mathbf{P}$ & 0.025 & 0.02 & $\begin{array}{c}\text { No } \\
\text { data }\end{array}$ & $\begin{array}{c}\text { No } \\
\text { data }\end{array}$ & $\begin{array}{c}\text { No data } \\
\text { da }\end{array}$ & $\begin{array}{c}0.020 \\
0.009\end{array}$ & $\begin{array}{c}\text { No } \\
\text { data }\end{array}$ & 0.007 & 0.006 \\
\hline $\mathbf{S}$ & 0.01 & 0.005 & $\begin{array}{c}\text { No } \\
\text { data }\end{array}$ & $\begin{array}{c}\text { No } \\
\text { data }\end{array}$ & $\begin{array}{c}\text { No data } \\
\text { data }\end{array}$ & $\begin{array}{c}0.005 \\
0.009\end{array}$ & $\begin{array}{c}\text { No } \\
\text { data }\end{array}$ & 0.003 & 0.003 \\
\hline $\mathbf{C r}$ & 1.2 & 1.0 & 1.5 & 0.5 & 0.2 & $\begin{array}{c}0.40- \\
0.60\end{array}$ & 0.37 & 0.22 & 0.377 & 0.599 \\
\hline $\mathbf{M o}$ & 0.25 & 0.5 & 0.6 & - & - & - & - & - & 0.027 & 0.030 \\
\hline $\mathbf{N i}$ & 0.25 & 0.8 & 1.5 & - & - & - & 0.060 & 0.04 & 0.166 & 0.117 \\
\hline $\mathbf{A l}$ & - & 0.06 & - & - & - & $\begin{array}{c}0.025- \\
0.065\end{array}$ & 0.030 & 0.057 & 0.016 & 0.028 \\
\hline $\mathbf{C u}$ & - & 0.40 & - & - & - & - & - & - & 0.322 & 0.237 \\
\hline $\mathbf{T i}$ & - & 0.05 & - & - & - & - & 0.040 & 0.034 & 0.052 & 0.043 \\
\hline $\mathbf{V}$ & - & 0.03 & - & - & - & - & 0.016 & 0.019 & 0.006 & 0.007 \\
\hline $\mathbf{B}$ & 0.005 & 0.003 & 0.005 & 0.002 & 0.001 & $\begin{array}{c}0.001- \\
0.004\end{array}$ & 0.001 & 0.002 & 0.0017 & 0.0025 \\
\hline $\mathbf{O t h e r s}$ & - & $\begin{array}{c}\mathrm{N}- \\
0.008\end{array}$ & - & - & - & - & - & $\begin{array}{c}\mathrm{N}- \\
0.007\end{array}$ & - & - \\
\hline
\end{tabular}

As known, manganese, silicon, chromium and boron increase deep hardenability of steel [4]. Based on extensive experimental studies, this article [8] offers an equation that makes it possible to evaluate the wear resistance of steel, depending on the quantity of the chemical elements. The wear coefficient $k_{c}$ is calculated by summing the multiples, which consist of a coefficient and the percentage amount of the chemical element in the alloy:

$$
k_{c}=240 \mathrm{C}+45 \mathrm{Mn}+35 \mathrm{Cr}+30 \mathrm{~V}+25 \mathrm{Mo}+10 \mathrm{~W} \text {. }
$$

Based on equation (1) the calculated ratio $\mathrm{k}_{\mathrm{c}}$, values are provided for all boron steels listed above and inserted in Table 2. Selected boron steels have very good deep hardenability after heat treatment, hardness in thickness does not change and varies between HRC $50 \pm 2$. Based on the information provided in article [8], it is possible to evaluate the non-alloy steel wear resistance. If compared to the wear resistance of benchmark steel $110 \mathrm{Mn} 13$, the wear coefficient for normalized steel C45 is 0.60 . This material and its qualities in normalized state are usually taken as a benchmark for comparison with other construction materials and alloys.

According to the authors of the article [9], wear resistance in their study was performed in accordance with the requirements of GOST 23.208-79.

The authors defined that resistance to wear at delivery for boron steel B27 is $80 \%$ of steel C45 wear resistance. Therefore, it is concluded that "without carrying a proper heat treatment - hardening and hardening/tempering type, the potential opportunities for high mechanical and chemical properties of these modern steels can be lost". Differences in assessment of wear resistance for the same material may be related to the fact that various assessment methods were used in studies. From the results it is possible to see that wear resistance for the same material can vary within wide limits. Such dispersion satisfies neither researchers, nor consumers - in this case, farmers who need reliable spare parts for 
plows. To get an overview of different boron steel suitability for manufacturing of coulter chisels, practical researches were performed in the field.

Wear resistant steel physical-mechanical and operational qualities

\begin{tabular}{|c|c|c|c|c|c|c|c|c|c|c|}
\hline \multirow{2}{*}{ Attribute } & \multicolumn{7}{|c|}{ Designation of material } \\
\cline { 2 - 12 } & $\begin{array}{c}\text { Hardox } \\
500\end{array}$ & $\begin{array}{c}\text { Relia } \\
500\end{array}$ & $\begin{array}{c}\text { AR } \\
500\end{array}$ & TBL & 495B & 922 & B27 & HSBS & B1 & B2 \\
\hline $\begin{array}{c}\text { Hardness } \\
\text { HRC } \pm 2\end{array}$ & 50 & 50 & 50 & 50 & 50 & 50 & 50 & 50 & 50 & 50 \\
\hline $\begin{array}{c}\text { Wear } \\
\text { coefficient } \boldsymbol{k}_{\boldsymbol{c}}, \\
\text { calculated }\end{array}$ & 1.85 & 1.83 & 2.12 & 1.40 & 1.24 & 1.36 & 1.29 & 1.12 & 1.39 & 1.43 \\
\hline $\begin{array}{c}\text { Wear } \\
\text { coefficient } \boldsymbol{k}_{\boldsymbol{c}} \text { in } \\
\text { other articles }\end{array}$ & $1.6-5.6$ & $3-6$ & $3-5$ & - & - & - & - & - & - & - \\
\hline
\end{tabular}

\section{Materials and methods}

The studied objects are plow chisels 063090 that were manufactured by Kverneland from boron steels B1 and B2 (see Table 1). To exclude high impact of many factors on the experimental results, both types of chisels were attached to one multihull plow. Podzolic soils generally consist of sand and clay. If the soil is composed of sand, abrasive wear is formed. Presence of clay in the soil causes adhesive wear. During treatment of loam soils both abrasive and adhesive wears are observed.

The farm "Maurinii" fields, which are located in Ozolnieki region, were selected. According to the research performed by the Department of Agricultural Chemistry Unit of Soils agricultural studies (not published), fields, in which the experiment was performed, are sod podzolated gley soil and sod gleyic soil. Grading composition of the soil consists of sand and clayed sand. Soil reaction is from neutral ( $\mathrm{pH}$ 6.0-7.6) to acid ( $\mathrm{pH} 4.8$ ).

Chisel wear is measured by changes in the distance from the bolt fastening to the spike of the chisel, $L 1$, and changes in chisel thickness [10]. The size of a new ploughshare $L 1$ is $110 \mathrm{~mm}$. The chisel is worn and needs to be turned, when this size has decreased to $85 \mathrm{~mm}$, to protect the supporting parts of the plough from wear. When the chisel is removed, its geometrical dimensions and mass can be measured.

To determine the value of the coefficient $k$ during processing of podzolic soil, experimental studies were carried out. Tractor Valtra 8950, with mounting 4 ploughs of semi-helicoidal body

KVU-40000 manufactured for the PGP plow group, equipped with chisels 063090 from the company "Original FRAM" (B1) and company "Bellota" (B2), was used. The chemical composition of materials B1 and B2 that the chisels used in the practical experiments were made of was determined with a stationary optical-emission spectrometer "Foundr Master".

Shape and dimensions of the chisel are shown in Figure 1.

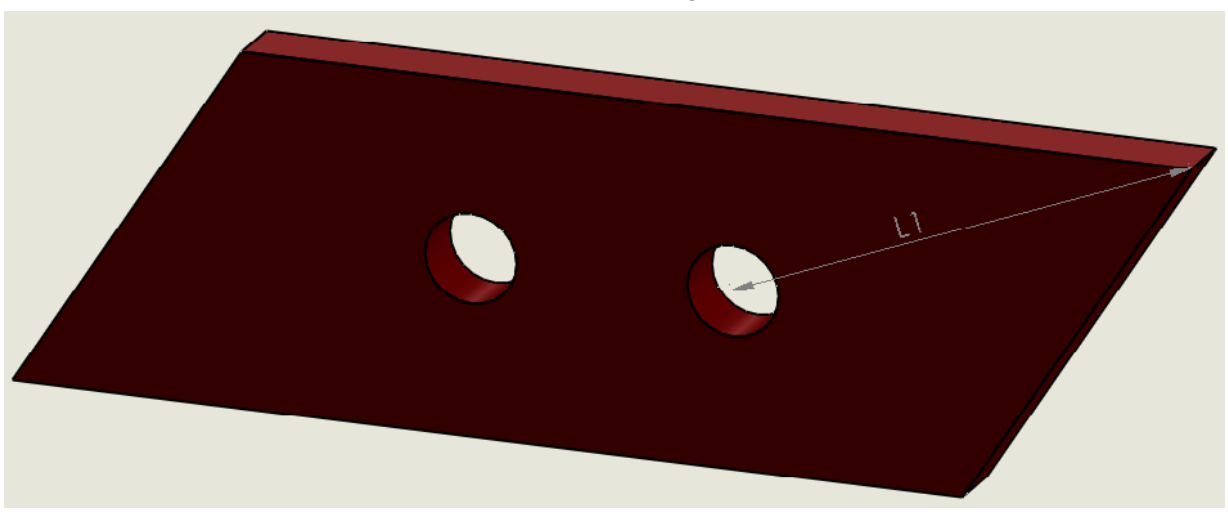

Fig. 1. Shape and dimensions of the chisel: $L 1$ - distance measurement 
Left and right side chisels from both companies were arranged symmetrically on the plow. The tillage width $-50 \mathrm{~cm}$. Tillage depth $-22 \mathrm{~cm}$. Speed of tillage $-2.5 \mathrm{~m} \cdot \mathrm{s}^{-1}$ (or $9 \mathrm{~km} \cdot \mathrm{h}^{-1}$ ). Moisture content in the soil $-14 \%$. Soil hardness $-1,8 \mathrm{MPa}$. The ploughs were equipped with new chisels, the mass of which, hardness and geometric size, including size $L 1$, were measured. At the beginning of tilling, the tractor odometer reading was registered as well. After tilling 25000 meters, the size $L_{1}$ was measured with a caliper, with accuracy $\pm 0.1 \mathrm{~mm}$. Such measures were taken every 25000 meters, up till $250000 \mathrm{~m}$, where the run was measured to accuracy $\pm 0.1 \mathrm{~km}$. Size $L_{1}$ was measured to an accuracy $\pm 2 \mathrm{~mm}$ and calculated as arithmetical average from 4 measurements; Wear was calculated as arithmetical average from 4 measurements. Chisel thickness was measured before screwed in position and right after removal from the plow, in between drillholes with accuracy $\pm 0.1 \mathrm{~mm}$. Chisels are weighted before screwing and right after removal from the plow with accuracy $\pm 1 \mathrm{~g}$.

\section{Results and discussion}

The measurement results are summarized together with the intensity of chisel wear in Table 3.

Table 3

Coulter chisel size and weight change during plowing

\begin{tabular}{|c|c|c|c|c|c|c|c|c|}
\hline Chisel & \multicolumn{4}{|c|}{ B1 } & \multicolumn{4}{|c|}{ B2 } \\
\hline $\begin{array}{c}\text { Run, } \\
\text { km }\end{array}$ & $\begin{array}{c}\operatorname{Size} L_{1}, \\
\mathbf{m m}\end{array}$ & $\begin{array}{c}\text { Wear } W, \\
\text { mm }\end{array}$ & $\begin{array}{c}\text { Thickness, } \\
\text { mm }\end{array}$ & Weight, g & $\begin{array}{c}\text { Size } L_{1} \\
\text { mm }\end{array}$ & $\begin{array}{c}\text { Wear } W \text {, } \\
\text { mm }\end{array}$ & $\begin{array}{c}\text { Thickness, } \\
\text { mm }\end{array}$ & Weight, g \\
\hline 0 & - & 0 & $12.2 \pm 0.2$ & $1308 \pm 22$ & $110.2 \pm 0.5$ & 0 & $12.0 \pm 0.2$ & $1320 \pm 20$ \\
\hline $50 \pm 2$ & $99.7 \pm 0.7$ & $10.3 \pm 0.7$ & - & - & $104.6 \pm 0.7$ & $5.4 \pm 0.7$ & - & - \\
\hline $100 \pm 2$ & $89.9 \pm 0.7$ & $20.1 \pm 0.7$ & - & - & $99.8 \pm 0.7$ & $10.2 \pm 0.7$ & - & - \\
\hline $125 \pm 2$ & $\begin{array}{c}84 \pm 0.7 \\
110 \pm 0.5\end{array}$ & $25 \pm 0.7 ; 0$ & $4.83 \pm 0.6$ & $343 \pm 34$ & $97.5 \pm 0.7$ & $12.5 \pm 0.7$ & - & - \\
\hline $150 \pm 2$ & $104.6 \pm 0.7$ & $5.4 \pm 0.7$ & - & - & $95.1 \pm 0.7$ & $14.9 \pm 0.7$ & - & - \\
\hline $200 \pm 2$ & $95.1 \pm 0.7$ & $14.9 \pm 0.7$ & - & - & $90.2 \pm 0.7$ & $19.8 \pm 0.7$ & - & - \\
\hline $250 \pm 2$ & $86.4 \pm 0.7$ & $23.6 \pm 0.7$ & $4.76 \pm 0.6$ & $337 \pm 34$ & $84.3 \pm 0.7$ & $25.9 \pm 0.7$ & $10.80 \pm 0.4$ & $956 \pm 27$ \\
\hline
\end{tabular}

Price for Chisel B1 is 2.40 EUR and for B2 - 3.40 EUR.

The experiment revealed that use of steels with very similar chemical composition can bring different results. Both chisels were made from boron steel, mark 2131 manufactured in the Swedish company SSAB. Steel B2 has $0.22 \%$ more chrome and $0.0008 \%$ more boron that gives 0.04 units higher wear resistance as estimated with the coefficient $k_{c}$. If chisel wear from the size $L_{1}$ end is compared, those chisels made from boron B2 descend about two times slower. Also boron B2 chisel thickness descended significantly less than that from boron B1.

The price for the chisel from material B2 is about 1 euro higher than from B1. This means more resources were consumed to manufacture this type of chisel. To increase wear resistance for soil and ground processing tools, high-temperature thermomechanical (hot-stamped) treatment is successfully applied. $25-40 \%$ is optimum strain deformation volume for machinery steel before hardening treatment. Application of isothermal processing methods gives positive impact [11]. As a result of this technology, the crystalline structure of the steel is changed and it gives a significant increase in wear resistance [12].

In order to assess the intensity of the wear process, most often the mass or volume of the worn down parts in relation to the distance run, or changes in a specific size are defined. Abrasive wear size is calculated according to equation (2)[10]:

$$
W=k P L / 3 H,
$$

where $W$-wear;

$k$ - particle coefficient of elasticity;

$P$ - amount of applied load;

$L$ - length of run;

$H$ - hardness of decrescent material. 
In this equation, the volume of wear can be calculated, if the chisel mass before and after use and boron steel density are known. The applied load shall be calculated analogous to other works (4).

As a result of calculation, the value of the coefficient $k$ is found:

$$
k=W \cdot 3 H / P \cdot L=\Delta m / \rho \cdot 3 \cdot H / \mathrm{P} \cdot L .
$$

Calculation for chisels from steel B1:

$$
k=\Delta m / \rho \cdot 3 \cdot H / P \cdot L=(965 / 7.85) \cdot 3.5000 / 275.6 \cdot 125000=0.0537 .
$$

Calculation for chisels from steel $\mathrm{B} 2$ :

$$
k=\Delta m / \rho \cdot 3 \cdot H / P \cdot L=(364 / 7.85) \cdot 3.5000 / 275.6 \cdot 250000=0.0101 .
$$

Calculations reflect that the wear resistance for steel B2 is more than 5.3 times higher than B1.

Using the practical experiment results and information from Table 3, calculation of wear of chisels $W_{l}$ in longitudinal direction $\mathrm{L} 1, \mathrm{~mm}$, in relation to the travelled distance $L, \mathrm{~km}$ :

$$
W_{l}=\Delta L_{1} \cdot L^{-1},
$$

where $\quad \Delta L 1=L 1_{b e g}-L 1_{\text {end }} ; L 1_{\text {beg }}$ - the measurement $L_{1}$ from the new chisel; $L 1_{\text {end }}$ is the measurement $L 1$ from the wear chisel.

Wear of chisels from steel B1 is:

$$
W_{l}=25 / 125=0.2 \mathrm{~mm} \cdot \mathrm{km}^{-1} .
$$

Wear of chisels from steel B2 is:

$$
W_{l}=25.7 / 250=0.103 \mathrm{~mm} \cdot \mathrm{km}^{-1} .
$$

If the L1 changes are considered, the wear resistance of the chisel from steel B2 is approximately 2 times higher than of the other chisel.

Chisel costs are calculated per $1 \mathrm{~km}$ road $C$. When working with chisels B1,

$$
C=\text { price } / 125=2.40 / 125=0.0192 \mathrm{EUR} \cdot \mathrm{km}^{-1} \text {. }
$$

Costs, working with chisels B2,

$$
C=3.40 / 250=0.0136 \mathrm{EUR} \cdot \mathrm{km}^{-1} .
$$

From an economic aspect, in this experiment it was cheaper to use chisels made from steel B2, provided by the company "Bellota". Use of wear resistant chisels allows reducing costs, downtime, service costs, and soil pollution with metals.

\section{Conclusions}

1. Tillage tool wear resistance depends on the material chemical composition, hardness, the changed structure resulting from the applied heat treatment technology and the soil physical and mechanical properties. Calculations reflect that the wear resistance by mass changes for steel B2 is more than 5.3 times higher than for steel B1.

2. During plowing, chisels from different manufacturers, but with similar chemical composition of the steel, wear with different intensity and have different wear character. Wear of chisels from steel B1 is $0.2 \mathrm{~mm} \cdot \mathrm{km}^{-1}$. Wear of chisels from steel B2 is $0.103 \mathrm{~mm} \cdot \mathrm{km}^{-1}$.

\section{References}

1. Tennenbaum M.M., Aronov E.L.. Modelirovanije gidroabrazivnogo processa iznašivanija detalıiei sel̦skohozjaistvennih mašin. V kn. Model̦irovanije trenija i iznosa. Moskva, 1976. pp. 93-100.

2. Handbook of Lubrication and Tribology. Vol.I. Application and Maintenance. Edited by George E. Totten. 2006.

3. Handbook of Lubrication and Tribology. Vol.II. Theory and Design. Edited by Robert W.Bruce.2012.

4. TATA steel- wear resistant boron steel. [online] [10.04.2017]. Available at: www.tatasteeleurope.com/en/products-and-services/flat/narrow-strip/boron/boron

5. Hardox steel. [online] [15.04.2017]. Available at: www.ssab.com/products/brands/hardox/products/hardox-500 
6. Realia steel. [online] [20.04.2017]. Available at: www.wearservice.ru/data/files/pdf/relia:pdf

7. Titus AR500 steel. [online] [20.04.2017]. Available at: www.titussteel.com/our-products/wearsteel/ar-500/

8. Serpik N.M., Kantor M.M. issledovanije iznašivanija stalej pri trenii v svobodnom abrazive.- V sb.: Iznos i trenije metallov i plastmass. Moskva, Nauka, 1964. S.29-52.

9. Frydman S.M., Letkowska B. Properties of boron steel after different heat treatments. Archive/2012/9/84-frydman_mtm12-paper_expanded.pdf

10. Ziemelis M., Verdins G. Wear of plough chisel during processing of podzolic soil. Jelgava.2016. $1177-1181 \mathrm{pp}$.

11. Trenije, iznašivanije i smazka. Spravočnik; kniga 1. Moskva, Mašinostrojenije. 1978. 400 str.

12. Napiorkowski J., Konat L., Ligier K/. The structural properties and resistance to abrasive wear in soil of CREUSABRO steel. Tribologia, 5-2016, 105-118 pp. 